\title{
Serum amyloid A and haptoglobin levels in crossbred cows with endometritis following different therapy
}

\author{
S. S. Biswal ${ }^{1,2}$, S. Das², S. Balasubramanian¹, D. N. Mohanty², K. Sethy² and M. Dasgupta ${ }^{2}$
}

1. Department of Animal Reproduction, Gynaecology and Obstetrics, Madras Veterinary College, Tamil Nadu Veterinary and Animal Sciences University, Chennai, Tamil Nadu, India; 2. Department of Animal Reproduction, Gynaecology and Obstetrics, College of Veterinary Science and Animal Husbandry, Orissa University of Agriculture and Technology, Bhubaneswar, Odisha, India.

Corresponding author: S. S. Biswal, e-mail: shuvranshu06@gmail.com, SD: dassrinibas@gmail.com,

SB: bala2716@yahoo.com, DNM: mohantydn@gmail.com, KS: babuivri@gmail.com, MD: mohuadgupta@gmail.com Received: 07-08-2014, Revised: 27-10-2014, Accepted: 04-11-2014, Published online: 11-12-2014

doi: 10.14202/vetworld.2014.1066-1070. How to cite this article: Biswal SS, Das S, Balasubramanian S, Mohanty DN, Sethy K, Dasgupta M (2014) Serum amyloid A and haptoglobin levels in crossbred cows with endometritis following different therapy, Veterinary World, 7(12): 1066-1070.

\begin{abstract}
Aim: To determine the serum variations of two major acute phase proteins, serum amyloid A (SAA) and haptoglobin (Hp) levels in crossbred endometritis cows following pre and post immunomodulation therapy.

Materials and Methods: 21 endometritis cows were randomly assigned to three groups ( $\mathrm{n}=7$ ) and treated with three different immunomodulators while seven healthy cows served as control. Uterine flushing collected from all animals was subjected to bacteriological study and serum samples were analyzed for SAA and Hp by sandwich ELISA method.

Results: Escherichia coli was most prevalent Gram-negative bacteria $\left(6.02 \times 10^{6} \mathrm{CFU} / \mathrm{ml}\right)$ while Staphylococcus $(0.86 \times$ $\left.10^{6} \mathrm{CFU} / \mathrm{ml}\right)$ and Streptococcus $\left(0.52 \times 10^{6} \mathrm{CFU} / \mathrm{ml}\right)$ were most predominant Gram-positive species isolated from uterine flushing. The pre-treatment SAA values $(\mu \mathrm{g} / \mathrm{ml})$ varied significantly $(\mathrm{p}<0.01)$ between the treatment groups whereas no difference was observed in post-treatment groups. No significant difference $(\mathrm{p}<0.01)$ was observed for Hp values between the treatment groups, but the mean SAA $(\mu \mathrm{g} / \mathrm{ml})$ and $\mathrm{Hp}(\mu \mathrm{g} / \mathrm{ml})$ levels were significantly $(\mathrm{p}<0.01)$ higher in pre-treatment when compared to post-treatment within the groups.
\end{abstract}

Conclusion: In the diagnosis and monitoring of bovine endometritis, both SAA and Hp might serve as reliable biomarkers.

Keywords: crossbred cows, endometritis, haptoglobin, serum amyloid A.

\section{I ntroduction}

Acute phase proteins (APPs) are large and varied group of glycoproteins in the serum that are unrelated to immunoglobulin. They are mainly synthesized by liver parenchyma cells as a part of acute phase response and released into the bloodstream in response to several stimuli like infection, inflammation, stress and trauma or tissue damage [1]. The APPs, whose concentrations increase due to inflammatory factors, are termed as positively reacting (e.g., haptoglobin [Hp], serum amyloid A [SAA], fibrinogen) and those whose concentrations decrease are negatively reacting (e.g., albumin, transferrin) [2]. The response pattern of individual APPs to various stressors and disease may differ in their serum concentration, which is a main disadvantage of APPs assay but still they serve as a nonspecific marker of clinical infection and used for prognostic purposes [3]. The main function of APPs is to defend the host against pathological damage and assist in the restoration of the homeostasis.

In bovine, to diagnose an inflammatory process is very difficult as the clinical symptoms are quite poor, and the classical parameters of the inflammatory

Copyright: The authors. This article is an open access article licensed under the terms of the Creative Commons Attributin License (http:// creative commons.org/licenses/by/2.0) which permits unrestricted use, distribution and reproduction in any medium, provided the work is properly cited. response are relatively slight and not very specific. Hematological tests that are used for diagnosis purpose sometimes fail because in bovine inflammation is not always followed by an increase in the leucocyte population [4]. So presently APPs are sensitive factors that enable very early and precise detection of inflammation in ruminants [5]. In cattle, mainly the concentration of two major APPs i.e. Hp and SAA in serum was elevated in association with several infection and inflammation [6].

In dairy cows, endometritis signifying inflammation of superficial layer of endometrium is the most common reproductive disorder which results in huge economic loss to farmers by decreasing milk production and increasing in calving to conception interval [7]. Its long-term consequences can cause irreversible changes of the genital tract leading to metritis and sterility [8]. Measuring the concentration of APPs has been applied to various viral diseases, mastitis, metritis and monitoring post-operational complications but there are very limited reports on APPs concentration in cows affected with endometritis.

Keeping the above facts in view, present study was undertaken to determine, whether an evaluation of APPs at selected time points during the treatment of endometritis with different immunomodulators could be used to monitor the course of treatment. We attempted to establish a relationship between the 
changes in concentration of investigated proteins and the clinical course of treatment.

\section{Materials and Methods}

Ethical approval

The approval for collecting blood samples and examination of cows was taken from Institutional Animal Ethics Committee.

\section{Study area}

The present study was carried out in the Department of Gynecology and Teaching Veterinary Clinical Complex, College of Veterinary Science and Animal Husbandry, Orissa University of Agriculture and Technology, Bhubaneswar from September 2012 to July 2013.

\section{Experimental design}

About 21 Jersey crossbred cows (first-fifth parity) at 40-90 days post-partum presented to the Teaching Veterinary Clinical Complex, with the history of cloudy discharge were selected for the study. All the cows were subjected to rectal examination and cows with clinical signs of endometritis (mucopurulent discharge) were included in the study. After the diagnosis of endometritis, the cows were randomly and equally assigned to three treatment groups $(n=7)$ and treated with three different drugs viz.: Oyster glycogen (OG) which enhances uterine neutrophilic influx and eliminates bacterial infection, prostaglandin $\mathrm{F}_{2} \alpha\left(\mathrm{PGF}_{2} \alpha\right)$, which considered to be pro-inflammatory molecule that stimulates production of proinflammatory cytokines and enhances phagocytosis and lymphocytic function and levamisole (LE), which increases phagocytosis by increasing the number of polymorph nuclear (PMN) cells and intracellular C-GMP level. Seven clinically healthy cows in estrus (40-90 days post-partum) served as control.

Group I (OG): 5 g of OG (Hi Media Laboratories Pvt. Ltd.) was reconstituted with $50 \mathrm{ml}$ of phosphate-buffered saline and given as intrauterine infusion; single dose.

Group II (PG): $500 \mu \mathrm{g}$ of $\mathrm{PGF}_{2} \alpha$ (Pragma, Intas Pharmaceuticals Ltd.) was administered through intramuscular route; single dose.

Group III (LE): $10 \mathrm{ml}$ of LE hydrochloride (Kalmisol, KAPL) was administered subcutaneous route on alternate days on three occasions.

Group IV (Control): Normal post-partum cows at 40-90 days at estrus presented for artificial insemination without institution of any therapy.

\section{Sample collection}

Uterine samples were collected aseptically from all three treatment groups before treatment and post treatment estrus and in control group at the time of estrus as per method described by Gilbert et al., [9] for bacterial isolation, identification and count. Briefly, the vulval lips and perineal area was thoroughly scrubbed with non-irritant soap solution followed by disinfection of the perineal area using $5 \%$ povidone iodine. Then a sterile plastic sheath was introduced into the cranial vagina and manipulated through the cervix into the uterus. $20 \mathrm{ml}$ sterile saline solution was infused into uterus; the uterus was massaged gently and uterine fluid sample was aspirated. The predominant bacterial count was made by agar plate count method. Blood was collected by jugular venipuncture prior to the institution of therapy and in post-therapy estrus. The collected blood was left for $2 \mathrm{~h}$ and then centrifuged at $1000 \mathrm{rpm}$ for $10 \mathrm{~min}$ at room temperature for serum collection. The collected serum was stored in cryovial at $-40^{\circ} \mathrm{C}$ until it was assayed. The SAA and Hp assay was done by solid phase sandwich ELISA kit (Life diagnostic, Inc.).

\section{Statistical analysis}

Mean values ( \pm standard error) for cows of four groups were computed. In order to monitor the magnitude of variation before and after treatment within the group Student's $t$-test was performed and to observe variations between the groups, the data were analyzed statistically using analysis of variance as per method suggested by Snedecor and Cochran [10].

\section{Results}

Various predominant bacterial species isolated from uterine samples and their counts are presented in Table-1. Of the total 28 uterine samples collected, bacterial species isolated were Escherichia coli (21.43\%), Streptococcus (17.86\%), Klebsiella (17.86\%), Staphylococcus (14.29\%), Micrococcus (10.71\%), Proteus (10.71\%) and Bacillus (7.14\%). The bacterial count $\left(10^{6} \mathrm{CFU} / \mathrm{ml}\right)$ for different bacterial species ranged between 0.52 (Streptococcus) and 8.60 (Micrococcus). In OG group, the concentration of Micrococcus was very high (8.60) followed by E. coli (6.20), Bacillus (4.50), Proteus (3.14), Klebsiella (0.93) Staphylococcus (0.86) and Streptococcus (0.52). In the post-treatment period, the E. coli and Micrococcus were only identified in OG group with negligible count.

In PG group, Micrococcus showed highest concentration (6.57) followed by E. coli (5.85), Bacillus (4.28), Proteus (3.14), and Streptococcus (1.46) whereas other microorganism had concentration $<1 \times 10^{6} \mathrm{CFU}$. In the post-treatment samples, only Streptococcus and Bacillus were eliminated, and enumeration of other bacteria showed a very low concentration. In LE group, predominant bacterial concentrations were observed to be Micrococcus (6.10) followed by E. coli (4.94), Proteus (4.24), Bacillus (3.70), Klebsiella (2.56) and Staphylococcus (1.40) whereas other microbes showed a very low concentration. The post-treatment bacterial counts were negative for Streptococcus, Klebsiella and Micrococcus whereas Bacillus, Proteus and E. coli showed a bacterial load of 2.12, 1.41 and 1.20, respectively with Staphylococcus as 0.02 concentrations. In control group, the bacterial load for E. coli, Bacillus 
Table-1: Predominant bacteria isolated and their count $\left(10^{6} \mathrm{CFU} / \mathrm{ml}\right)$ before and after treatment.

\begin{tabular}{|c|c|c|c|c|c|c|c|}
\hline \multirow[t]{3}{*}{ Microorganism } & \multirow{3}{*}{$\begin{array}{c}\text { Frequency } \\
(\%)\end{array}$} & \multicolumn{6}{|c|}{ Treatment groups } \\
\hline & & \multicolumn{2}{|c|}{ Group I (OG) } & \multicolumn{2}{|c|}{ Group II (PG) } & \multicolumn{2}{|c|}{ Group III (LE) } \\
\hline & & Pre & Post & Pre & Post & Pre & Post \\
\hline E. coli & $6(21.43)$ & 6.20 & 0.63 & 5.85 & 0.02 & 4.94 & 1.20 \\
\hline Staphylococcus & $4(14.29)$ & 0.86 & - & 0.78 & 0.04 & 1.40 & 0.02 \\
\hline Streptococcus ( $\beta$ hemolyticus) & $5(17.86)$ & 0.52 & - & 1.46 & - & 0.98 & - \\
\hline Proteus & $3(10.71)$ & 3.20 & - & 3.14 & 0.91 & 4.24 & 1.41 \\
\hline Bacillus & $2(7.14)$ & 4.50 & - & 4.28 & - & 3.70 & 2.12 \\
\hline Klebsiella & $5(17.86)$ & 0.93 & - & 0.87 & 0.20 & 2.56 & - \\
\hline Micrococcus & $3(10.71)$ & 8.60 & 0.24 & 6.57 & 1.40 & 6.10 & - \\
\hline
\end{tabular}

E. coli=Escherichia coli, OG=Oyster glycogen, LE=Levamisole, PG: Prostaglandin

and Micrococcus were 2.10, 1.30 and 1.15 with the absence of other contaminants.

The concentration of SAA and Hp before and after treatment with immunomodulators in endometritis cows and normal cyclic cows are presented in Table-2. The pre-treatment SAA values ranged from $33.97 \pm 2.14$ to $35.42 \pm 0.58 \mu \mathrm{g} / \mathrm{ml}$ while the post-treatment values ranged from $13.29 \pm 1.62$ to $18.92 \pm 1.48 \mu \mathrm{g} / \mathrm{ml}$. For the control group, the SAA value was $16.80 \pm 1.62 \mu \mathrm{g} / \mathrm{ml}$. The analysis of variance in the pre-treatment period revealed a significant difference $(\mathrm{p}<0.01)$ among various groups while no significant difference could be observed among post-treatment values. The post-treatment values of SAA were significantly lower $(\mathrm{p}<0.01)$ from pre-treatment values for Group I, II, III.

The pre-treatment $\mathrm{Hp}$ values ranged from $80.19 \pm 7.29$ to $81.56 \pm 4.22 \mu \mathrm{g} / \mathrm{ml}$ while the post-treatment values ranged from $21.05 \pm 1.63$ to $24.57 \pm 3.65 \mu \mathrm{g} / \mathrm{ml}$. For control group, the Hp value was $22.39 \pm 1.93 \mu \mathrm{g} / \mathrm{ml}$. The analysis of variance did not reveal any significant difference either in pre and post treatment values among the experimental groups. There was a significant reduction $(\mathrm{p}<0.01)$ of Hp values between pre and post treatment period during post-treatment estrus for each treatment groups.

\section{Discussion}

The present study revealed that bacteria $E$. coli followed by Streptococcus and Klebsiella spp. were found to be accountable for endometritis in cows. The type of bacterial isolates observed in the present study was comparable to Kusum et al. [11]. Shweta [12] also reported the isolation of these organisms from uterine flushing of cows suffering from endometritis. But Bonnett et al. [13] reported that Actinomyces pyogenes was more prevalent followed by $E$. coli and Streptococcus in endometritis cows. Bacterial elimination was highest in OG group justifying its immunomodulatory effect to eliminate the bacterial infection by the chemotactic action that increased the PMN cell migration to uterus [14]. In PG group, there was a marked decrease in the bacterial load and bacterial species like Streptococcus and Bacillus were completely absent, which was due to the systemic immunomodulation. In post-treatment sampling for LE group, Proteus, Klebsiella and Micrococcus were negative whereas after treatment bacterial count was moderately low. This decrease in bacterial count in LE group was due to its potent thymomimetic action which resulted in the systemic immunomodulation.

SAA is an apolipoprotein $(9-14 \mathrm{KDa})$ that helped in uptake and removal of cholesterol from inflammatory site. It has different isoforms that are expressed constitutively at different levels in response to inflammatory stimuli [15]. SAA1 and SAA2 are expressed in liver while inflammation whereas SAA3 is produced from distinct tissues like adipose tissue, mammary gland and intestinal cells [16]. SAA4 does not respond to external stimuli [17]. SAA mainly scavenged the cholesterol from dying cells and prevented the accumulation of atherosclerotic plaques. It also directly bound to Gram-negative bacteria leading to opsonization of the target pathogens, inhibition of phagocyte burst and platelet activation [18]. SAA is a rapidly reacting APPs which showed a higher increase in concentration in case of acute as compared to chronic inflammation [19].

In this study, the pre-treatment SAA values in endometritis cows significantly decreased after treatment with immunomodulators. The present observations corroborated with the study of Ceciliani et al. [20] who reported that the concentration of SAA in healthy cows was $1.3 \pm 0.4 \mathrm{mg} / \mathrm{L}$. Chan et al. [21] showed the SAA concentration decreased to $<51.9 \mathrm{mg} / \mathrm{L}$ during 1st week after parturition. The decrease in concentration of SAA after treatment to a value, which was nearly equal to normal animals, indicated substantial remission of infective process irrespective of immunomodulators employed.

Hp is a glycoprotein composed of two $\alpha$ and two $\beta$ chains which are connected by disulfide bridges [22]. Hp binds to free hemoglobin released from erythrocytes with high affinity and reduced the oxidative damage to itself and albumin [23]. Hp - hemoglobin complex reduced the availability of the iron residue for bacterial growth and therefore it had an indirect antibacterial activity [24]. It has also effect on angiogenesis, chaperon activity and also act as a proinflammatory mediator. Various studies have indicated the 
Table-2: SAA $(\mu \mathrm{g} / \mathrm{ml})$ and $\mathrm{HP}(\mu \mathrm{g} / \mathrm{ml})$ values in endometritis cows before and after treatment $(\mathrm{mean} \pm \mathrm{SE})$.

\begin{tabular}{|c|c|c|c|c|c|c|}
\hline \multirow[t]{3}{*}{ Groups } & \multicolumn{6}{|c|}{ APPs } \\
\hline & \multicolumn{3}{|c|}{ SAA } & \multicolumn{3}{|c|}{ Hp } \\
\hline & Pre-treatment & Post treatment & t-value & Pre-treatment & Post treatment & t-value \\
\hline Group I (OG) & $35.40 \pm 1.56$ & $13.29 \pm 1.62$ & $9.56 * *$ & $81.30 \pm 3.98$ & $24.57 \pm 3.65$ & $10.51 * *$ \\
\hline Group II (PG) & $35.42 \pm 0.58$ & $16.62 \pm 2.17$ & $8.96 * *$ & $80.19 \pm 7.29$ & $24.19 \pm 2.79$ & $7.17 * *$ \\
\hline Group III (LE) & $33.97 \pm 2.14$ & $18.92 \pm 1.48$ & $5.77 * *$ & $81.56 \pm 4.22$ & $21.05 \pm 1.63$ & $13.37 * *$ \\
\hline Group IV (control) & $16.80 \pm 1.62$ & - & - & $22.39 \pm 1.93$ & - & - \\
\hline F value & $33.19 * *$ & $1.37^{\mathrm{NS}}$ & - & $0.018^{\mathrm{NS}}$ & $0.390^{\mathrm{NS}}$ & - \\
\hline
\end{tabular}

$* * \mathrm{p}<0.01$, Ns Not-significant, APPs=Acute phase proteins, SAA=Serum amyloid A, Hp=Haptoglobin, OG=Oyster glycogen, $\mathrm{LE}=$ Levamisole, $\mathrm{PG}=$ Prostaglandin, $\mathrm{SE}=$ Standard error

significance of Hp in many inflammatory conditions like mastitis, pneumonia, enteritis, peritonitis, endocarditis, abscess and lameness. It is also induced in cows with fatty liver syndrome and starvation.

In our study, Hp $(\mu \mathrm{g} / \mathrm{ml})$ level in cows affected with endometritis significantly decreased after treatment with immunomodulators. It indicated that after treatment with immunomodulators irrespective of types the cows were reviving from infection. Hp acts synergistically along with immunomodulators for elimination of infection. The present study corroborated with the study of Ceciliani et al. [20] who reported a value of $<0.1 \mathrm{~g} / \mathrm{L}$ for normal healthy cows. Dubuc et al. [25] reported Hp concentration $>0.8 \mathrm{~g} / \mathrm{L}$ in 1 st week of parturition not only prone to metritis but also to endometritis.

\section{Conclusion}

The present study investigated SAA and Hp concentrations in crossbred cows suffering from clinical endometritis following treatment with different drug regimen. Based on the results it could be inferred that assessment of both SAA and Hp concentrations at different time points during treatment could serve as reliable biomarkers for both diagnosis and monitoring of clinical endometritis in cows.

\section{Authors' Contributions}

SD and DNM designed the study. SSB and MDG collected samples for study and carried out the work. SB and KS assisted in manuscript writing and cross scrutiny. All authors read and approved the final manuscript.

\section{Acknowledgments}

The authors are thankful to Principal scientist of Animal Biotechnology Department, NDRI, Karnal, Dr. A. K Mohanty for co-operation and facilities provided for the estimation SAA and Hp. The fund for the study was provided by Department of Animal Reproduction, Gynecology and obstetrics, College of Veterinary Science and Animal Husbandry, Bhubaneswar, Odisha.

\section{Competing I nterests}

The authors declare that they have no competing interests.

\section{References}

1. Cray, C., Zaias, J. and Altman, N.H. (2009) Acute phase response in animals: A review. Comp. Med., 59(6): 517-526.

2. Eckersall, P.D. and Bell, R. (2010) Acute phase proteins: Biomarkers of infection and inflammation in veterinary medicine. Vet. J., 185: 23-27.

3. Lauritzen, B., Lykkesfeldt, J., Skaanild, M.T., Angen, Q., Nielsen, J.P. and Friis, C. (2003) Putative biomarkers for evaluating antibiotic treatment of Actinobacillus pleuropneumoniae infection in pigs. Res. Vet. Sci., 74: 271-277.

4. Taylor, J.A. (2006) Leukocyte responses in ruminants. In: Feldman, A.B.F., Zinkl, J.G. and Jain, N.C., editors. Schalm's Veterinary Hematology. Blackwell Publishing Professional, Iowa, USA. p391-404.

5. Kent, J. (1992) Acute phase proteins: Their use in veterinary diagnosis. Br. Vet. J., 148(4): 279-282.

6. Bannikov, G., Hinds. C., Rajala-Schultz, P., Premanandan, C., Rings, D. and Lakritz, J. (2011) Serum haptoglobin-matrix metalloproteinase 9 (Hp-MMP 9) complex as a biomarker of systemic inflammation in cattle. Vet. Immunol. Immunopathol., 139: 41-49.

7. Markandeya, N.M. and Deshmukh, V.V. (1995) A study on antibiotic sensitivity pattern of bacterial isolates from repeat breeding cows. Int. J. Anim. Sci., 10: 337-338.

8. Sheldon, I. M., Nokes. D.E., Rycroft, A. and Dobson, H. (2009) Effect of intrauterine administration of estradiol on postpartum uterine bacterial infection in cattle. Anim. Reprod. Sci., 8: 13-23.

9. Gilbert, R.O., Shin, S.T., Guard, C.L., Erb, H.N. and Frajblat, M. (2005). Prevalence of endometritis and its effects on reproductive performance of dairy cows. Theriogenology, 64(9): 1879-1888.

10. Snedecor, G.W. and Cochran, W.G. (1994) Statistical Methods. $8^{\text {th }}$ ed. Low State University Press, USA.

11. Kusum, K., Roy, G.P., Akhtar, M.H. and Singh, A.P. (2003) Microbial status and antibiogram of the uterine isolates in endometric crossbred cows. Indian J. Anim. Sci., 73: $1039-1040$.

12. Shweta, S. (2003) M.V.Sc., Thesis Submitted to College of Veterinary and Animal Sciences, CSK, Himachal Pradesh Krishi Vishvavidyalaya, Palampur, India.

13. Bonnett, B.N., Martin, S.W. Gannon, V.P.J. Miller R.B. and Etherington, W.G. (1991) Endometrial biopsy in Holstein dairy cows. Rev. Can. Res. Vet., 55(5): 168-173.

14. Sarma, O.K., Singh, B., Singh, M.P., Tiwary, B.K. and Sinha, M.P. (2010) Efficacy of immunomodulators for treatment of endometritis in cows. Indian J. Anim. Repod., 31(2): 59-61.

15. Takahashi, E., Kuwayama, H., Kawamoto, K., Matsui, T. and Inokuma, H. (2009) Detection serum amyloid A isoforms in cattle. J. Vet. Diagn. Invest., 21(6): 874-877.

16. Ametaj, B.M., Hosseini, A., Odhiambo, J.F., Iqbal, S., Sharma, S., Deng, Q., Lam, T.H., Farooq, U., Zebeli, Q. and Dunn, S.M. (2011) Application of acute phase proteins for monitoring inflammatory states in cattle. In: Veas, F., editor. Acute Phase Proteins as Early Non-Specific Biomarkers of 
Human and Veterinary Diseases. In Tech, Rijeka, Croatia. p299-354.

17. De Beer, M.C., Yuan, T., Kindy, M.S., Asztalos, B.F., Roheim, P.S. and de Beer, F.C. (1995) Characterization of constitutive human serum amyloid a protein (SAA4) as an apolipoprotein. J. Lipid Res., 36(3): 526-534.

18. Mukesh, N., Bionaz, M., Graugnard, D.E., Drackley, J.K. and Loor, J.J. (2010) Adipose tissue depots of Holstein cows are immune responsive: Inflammatory gene expression in vitro. Domest. Anim. Endocrinol., 38(3): 168-178.

19. Horadagoda, N.U., Knox, K.M., Gibbs, H.A., Reid, S.W., Horadagoda, A., Edwards, S. E. and Eckersall, P.D. (1999) Acute phase proteins in cattle: Discrimination between acute and chronic inflammation. Vet. Rec., 144(16): 437-441.

20. Ceciliani, F., Ceron, J.J., Eckersall, PD. and Sauerwein, H. (2012) Acute phase proteins in ruminants. J. Proteomics, 75: 4207-4231.

21. Chan, J.P.W., Chang, CC., Hsu, WI., Liu, WB. and Chen, TH.
(2010) Association of increased serum acute-phase protein concentrations with reproductive performance in dairy cows with postpartum metritis. Vet. Clin. Pathol., 39(1): 72-78.

22. Kurosky, A., Barnett, D.R., Lee, T.H., Touchstone, B., Hay, R.E., Arnott, M.S., Bowman, B.H. and Fitch, W.M. (1980) Covalent structure of human haptoglobin: A serine protease homologus amino acid sequence/plasminogen/prothrombin/protein evaluation. Proc. Natl. Acad. Sci. U S A., 77(6): 3388-3392.

23. Yang, F.M., Haile, D.J., Berger, F.G., Herbert, D.C., Van Beveren, E., and Ghio, A.J. (2003) Haptoglobin reduces lung injury associated with exposure to blood. Am. J. Physiol. Lung Cell Mol. Physiol., 284(2): L402-L409.

24. Murata, H., Shimada, N. and Yoshioka, M. (2004) Current research on acute phase proteins in veterinary diagnosis: An overview. Vet. J., 168(1): 28-40.

25. Dubuc, J., Duffield, T.F., Leslie, K.E., Walton, J.S. and Leblanc, S.J. (2010) Risk factors for postpartum uterine diseases in dairy cows. J. Dairy Sci., 93(12): 5764-5771. 